\title{
19
}

\section{Two Sides of the Same Coin: Student-Faculty Perspectives of the Course Syllabus}

\author{
Jeanette McDonald \\ Wilfrid Laurier University \\ Gillian Siddall \\ Lakehead University \\ Deena Mandell \\ Wilfrid Laurier University \\ Sandy Hughes \\ Wilfrid Laurier University
}

Course syllabi play an important role in teaching, learning, and course design. They serve multiple functions and audiences and represent the end product of a scholarly process. In the following article, select findings from a mixed methods study examining how faculty and students conceptualize course syllabi are presented, specifically the design implications of what faculty include in their syllabi and those items students perceive to be most important and attend to most often throughout the course.

\section{Introduction and Context}

Cor many in higher education, the syllabus has (i.e., part and parcel of delivering a course; required by one's collective agreement): one that serves basically as an outline of topics to be covered, a weekly schedule, and a listing of tests and assignments with associated weightings. In more recent years, however, faculty have increasingly acknowledged the potential of the syllabus to serve as a document that can articulate the connections among learner/learning outcomes, assessments, course content, pedagogical practice, and the professor's teaching philosophy what Biggs (1996) calls "constructive alignment."

The educational literature mirrors a growing 
recognition of the multiple functions and potential of the syllabus to support teaching and learning. No longer just a precursor to outline and teach course content alone, the syllabus serves ever more complex functions and varied audiences. Parkes and Harris (2002) articulate three broad functions of a syllabus: a contract, a permanent record, and a learning aid, while Grunert O'Brien, Millis, and Cohen (2008) further refine these functions from a learning-centred perspective. Others still point to the syllabus as a communication device (Altman \& Cashin, 1992; Garavalia, Hummel, Wiley, \& Huitt, 1999; Matejka $\&$ Kurke, 1994) and as a roadmap (Nilson, 1998). Each function reflects a different educational purpose and speaks to the varied end-users of course syllabi (e.g., petition committees, other program instructors and potential students, accrediting bodies, academic support staff, and administrators, to name a few).

While traditionally the design of the syllabus has been guided by its audience (mainly students) and the organization of the course (Hockensmith, 1988), other influences, as suggested above, now come into play. Consequently, the design of one's syllabus necessitates a more learned and informed approach than might previously have been the case. Boyer's (1990) expanded conception of scholarship (i.e., teaching, integration, application, and discovery) provides a framework to capture the complexity and the scholarliness associated with the syllabus and its design (Nilson, 2008; Shulman, 2004). To this end, the educational literature provides limited but helpful information in the form of syllabus checklists, research-informed best practices, and, to a lesser extent, reports from a small sample of studies examining course syllabi specifically in relation to their design, presentation, and pedagogical application.

With this context in mind, and a desire to have more institutionally specific data about what we know (or don't know) about the design and use of syllabi by professors and students, a group of faculty and educational developers from two primarily undergraduate Ontario universities came together in 2007/2008 to design and implement a syllabus study. A multi-pronged approach was taken, which included the following: 1) an item analysis of undergraduate and graduate course syllabi; 2) a content analysis of learning objectives; and 3) a survey of undergraduate and graduate students.

The confines of this article are too narrow to report fully on our methodology and all aspects of our analysis and findings. More detailed information on each research step, the associated research tools, as well as resources and some preliminary study findings are available at the project wiki: http://www.nutshell. wikispaces.com. Here, we offer insights from our research based on a comparison of what faculty actually include in their syllabi and what students deem to be important and attend to during the term. Insights, speculations, and recommendations are interwoven into the discussion, ending with some concluding thoughts and next steps.

\section{What Do Instructors Include in Their Course Syllabi?}

Assessing what professors typically include in their course syllabi constituted the first step in our research project. Naturally, we anticipated that certain items or categories of items would be consistently reported, and indeed this proved to be the case. We were less certain in our anticipation of the impact of personal, disciplinary, or professional influences on design. Table 1 provides highlights of items we discovered from our analysis of 361 syllabi (representing a broad spectrum of disciplines) and the approximate frequency (rounded-up/down) of their occurrence.

Not surprisingly, instructors were consistent in providing some types of information on their syllabi and less consistent in referencing others.

The absence or presence of a given item and the degree to which it was reported left us with as many questions as answers. Without further instructor follow-up, the mere presence of an item did not reveal the reason for its inclusion, and the absence of an item did not preclude the possibility that the professor communicated that item to students in other ways. We could only speculate (and hope) that any item deemed to be important would be addressed either verbally in class, via email, on the course website, or in a handout. Fortunately, student feedback in the form of 300 plus com- 


\section{Table 1}

Comparative Summary of Syllabus Items Referenced by Faculty

\begin{tabular}{|c|c|}
\hline More common items & Less common items \\
\hline $\begin{array}{l}\text { - list of assessments }(99 \%) \\
\text { - } \text { weightings of tests and assignments }(97 \%) \\
\text { - list of course readings }(94 \%) \\
\text { - basic course and contact information }(80-98 \%) \\
\text { - } \text { outline of course topics }(86 \%) \\
\text { - } \text { brief description of tests and assignments }(86 \%) \\
\text { - course description }(76 \%) \\
\text { - course reading schedule }(76 \%) \\
\text { - class meeting schedule }(70 \%) \\
\text { - course objectives }(69 \%)\end{array}$ & $\begin{array}{l}\text { - university policies (e.g., plagiarism } 52 \% \text {, spe- } \\
\text { cial needs } 48 \% \text { ) } \\
\text { - course/instructional approach (40\%) } \\
\text { - detailed information about grading criteria } \\
(32 \%) \text { and individual assessments as a whole } \\
(36 \%) \\
\text { - course policies (e.g., attendance } 33 \% \text {, late as- } \\
\text { signments } 25 \% \text {, course conduct } 10 \% \text { ) } \\
\text { - student success strategies (e.g., study sug- } \\
\text { gestions } 4 \% \text {, additional materials such as for- } \\
\text { mulas } 2 \% \text { ) } \\
\text { - academic support services (e.g., writing } 3 \% \text {, } \\
\text { learning } 2 \% \text {, library < } 1 \% \text { ) }\end{array}$ \\
\hline
\end{tabular}

ments confirmed this to be the case; students identified detailed grading and assignment information as one, if not the most common, example to be elaborated on by their professor outside of the syllabus. Given its lower frequency of reporting (i.e., $32-36 \%)$, this finding is not surprising.

\section{Learning objectives}

We were surprised to discover that the provision of learning objectives on syllabi was not higher (only $69 \%$ ). We anticipated objectives would receive greater mention (i.e., $80-100 \%$ ) by faculty, as they form the basis of sound course design (i.e., what to include, how to organize, what and how to assess, etc.), are linked to improved student performance (see Schonfeld, Rasmussen, Nieto, \& Sims, 1989), and are an expression of program-level objectives. Even in our content analysis of syllabi, only $60 \%$ (23 of 38 reviewed) had a separate section for course objectives - a finding consistent with Mager's (1984) earlier reporting that little distinction is made by instructors between the course description (i.e., content and procedures) and the learning objectives (i.e., desired student learning). Thirty-plus years later we were surprised to see that this is still the case.

On the student side, objectives fell nearly last in what they reported looking at first $(<2 \%)$.
While the students acknowledged their overall importance $(76 \%)$, they referenced them only $17 \%$ of the time throughout the semester, and only slightly more $(23 \%$ of the time) during the exam period. These findings overall suggest to us that faculty and students neither embrace nor value (or even know about) the pedagogical function of objectives. While it is possible that objectives may have been articulated to students by their professors during class time versus the syllabus, and that not all professors use the term "objectives," these findings imply that more needs to be done systemically at the institutional, program, and individual level to situate and integrate the formation and application of objectives in teaching and learning. As a start, this can be done by crafting separate sections for the objectives and course description, and using the latter strategically to provide an overview of the course as well as a framework and context to position course objectives. From the latter, then, links to the assessments can clearly be drawn.

\section{What Do Students Think Should be Included in a Syllabus?}

\section{Assessment}

One of several questions we asked students to rate 
was the importance of various syllabus items $(1=$ least important, 5 = most important; refer to student survey ${ }^{1}$ ). From a list of 18 items (reported most frequently in the literature and included in the item analysis tool), the top four ranked "most important" all had to do with assessment: a listing of course assessments with detailed guidelines and grading information (71\%), a listing of assignment/test weightings (71\%), a listing of course assessments/evaluations in general (80\%), and assessment/evaluation due dates (82\%). All but one of these items was included by faculty on their syllabi 80 to 99 percent of the time according to our item analysis. The exception had to do with the provision of detailed grading and assessment information. For this item, faculty were half as likely $(35 \%)$ to provide the information that students deemed most important (71\%) even though, as noted previously, there was some indication from students' written comments that this was addressed by other means during the course. Responses to two other survey questions reinforced the importance of assessment information to students: one, that students looked at the percentage weightings (24\%) and the list of course assessments (23.5\%) first and second respectively when viewing a syllabus for the first time, and two, that they consistently attended to assessment information (including grading criteria, due dates, etc.) throughout the semester. Only scheduling information outranked assessment information in the first third (i.e., weeks 1 to 4 ) of the term by a slim margin.

These findings suggest that assessment is a central feature and information piece for inclusion in a syllabus, and that more rather than less information is desired by students. In terms of design, instructors may want to consider placing a listing of course assessments with their associated weightings at the beginning of their syllabus, and more detailed information aimed at supporting the learning process and learner success, in the latter part or appendix of their syllabus. Here, the flexibility of an online syllabus to offer more robust information may be worthy of consideration, especially in light of comparative data from a 2003 study (see Parkes, Fix, \& Harris,
2003) revealing that preference for a paper-only syllabus has decreased by half ( $88.5 \%$ then, $42 \%$ now), preference for the availability of both a paper and an electronic version has increased more than six-fold ( $7 \%$ then, $46 \%$ now), and preference for an electronic syllabus alone has tripled ( $4 \%$ then, $13 \%$ now).

\section{Scheduling}

Following assessment, the next "most important" set of items ranked by students were scheduling related (i.e., reading 49\%, meeting 36\%, learning activities, $30 \%)$. From there, contact information $(39 \%)$, student responsibilities $(32.5 \%)$, course information (27\%), the course description (27\%), and learning materials (26\%) came next. Other than student expectations and responsibilities (57\%), the aforementioned items were consistently represented by faculty in their syllabi 70 or more percent of the time. In terms of what students "attended to most" during the semester (versus ranked important), scheduling information placed first or second throughout the term, and third during the exam period, thereby underscoring the importance of this information. Learning materials too were consistently ranked third throughout the semester, reinforcing their perceived importance, while general course information had primacy in the first third of the term (4th of 11 items) only. What this suggests is a need for greater transparency (e.g., detailed scheduling information and expectations) and specificity in syllabi to guide students in navigating the course and achieving the desired learning outcomes.

\section{Other findings of interest}

Not surprisingly, those items deemed least important by students were related to policy (10\%) and support services information (9\%). Comparatively, reference to course and university policies by professors ranged from four to 52 percent (even mandated policies such as academic misconduct and special needs), while support services information was rarely mentioned at all, the exception being a campus safe-walk program. As a contract, the importance of policy information

\footnotetext{
${ }^{1}$ Survey available at http://nutshell.wikispaces.com/Student+Survey
} 
within a syllabus cannot be overestimated, as the syllabus often forms the basis of decisions in petition cases when issues such as grade disputes arise. As such, policy information may best be located near the end of the syllabus or within the section to which it is related (e.g., late assignments policy in the assessment section). Perhaps the status of policy statements and support services information would be higher if these elements were included in syllabi more often and reinforced by other means (e.g., integrated into class activities and discussion).

\section{What Else Did Students Tell Us?}

\section{Use of syllabus}

Beyond what students attended to most during the term and items they considered to be most important for inclusion in course syllabi, we learned that students use the syllabus in various ways: as a reference tool $(88 \%)$, time management tool $(80 \%)$, study tool (53\%), and documentation tool (32\%). Given the emphasis placed on scheduling information and assessment due dates, the first and second uses are in alignment with what has already been reported on above. One example shared by students in this regard was the collation of schedules into one master document, whether cut-and-pasted manually if paperbased, or electronically if provided online. This, they reported, helped them to plan and manage course information in their preferred way. The syllabus as study tool was less straightforward. While the subject matter to be studied is standard content in most syllabi, the availability of objectives (of which the quality and clarity ranged considerably) and study supports (e.g., practice questions, study tips, rubrics, strategies for learning in the discipline - see Parkes \& Harris, 2002) to guide student learning, ranged from moderately present to non-existent. Greater attention, therefore, to the learning tool function of the syllabus is needed (both on paper and its use in class) to support learners, especially in light of findings that significantly more first-year students - inexperienced university learners - than fourth-year students ( $\mathrm{p}=$ .036) reported using the syllabus as a study aid. Finally, in the context of the syllabus as a documenta- tion tool, students commented that they used their syllabus as a recording device (e.g., to record assignment and test grades).

Two final items worthy of note speak to factors which most influence a student's decision to take a given course and the learner's perception of what constitutes a user-friendly document. Of the 13 influences (refer to survey) students had to choose from, eight were directly related to the syllabus. Of these eight, the course description and overview were primary $(39 \%)$, followed by assessment information (17-28.5\%), instructor approach (23\%), and the amount of readings (16\%). Based on the more than 800 comments about syllabus user-friendliness, the design elements students most appreciated included clarity (i.e., language and format), conciseness (i.e., complete information), consistency of formatting (e.g., sub/headings, bulleted items, font size/type), sound organization (e.g., easy to locate specific information or sections), and a friendly but professional tone (e.g., approachable language). Again, each of these findings has implications for design that move the syllabus from its contractual and permanent document functions to syllabus as learning aid.

\section{Summary and Conclusions}

So, what does this all mean? Well, in terms of what professors include in their syllabi and what students look for, use, and need, there is alignment in many cases between the two. Having said this, we have provided several recommendations to aid in the design of course syllabi and identified areas in the discussion above where stronger linkages can be made and reinforcement by other means (which may already be happening) integrated into the teaching and learning process. In this, we concur with other educational scholars (Nilson, 2008; Shulman, 2004) that the design of a syllabus should be scholarly in approach and that syllabus authors should strategically consider the full range of syllabus functions, pedagogical applications (e.g., teaching tool), and the multitude of potential end-users given the teaching context, subject matter, and discipline.

As our research has raised as many questions 
as answers, we continue to analyze the data collected so far, while at the same time explore a second phase of research that involves follow-up with faculty with a specific focus on objectives and syllabus construction, and how they conceive their relationship to teaching, learning, and curricular design more broadly.

Individually and collectively the project team has gained so much already, resulting in changes to what we include in our own syllabi, how we use them in our practice, and how we support others in the design of syllabi and their placement within the larger context of academic programs and the institution as a whole.

\section{Special Thanks}

The authors would like to acknowledge the work and support of the research assistants associated with this project: Sandra Ayerst and Kendra Hollidge of Wilfrid Laurier University, and Divine Afflu of Lakehead University.

\section{References}

Altman, H.B. \& Cashin, W.E. (1992). Writing a syllabus. IDEA Paper No. 27. Center for Faculty Evaluation and Development, Kansas State University, Manhattan, KS.

Biggs, J. (1996). Enhancing teaching and learning through constructive alignment. Higher Education, 32, 347-364.

Boyer, E.L. (1990). Scholarship reconsidered: Priorities of the professoriate. Princeton, NJ: The Carnegie Foundation for the Advancement of Teaching.

Garavalia, L.S., Hummel, J.H., Wiley, L.P., \& Huitt, W.G. (1999). Constructing the course syllabus: Faculty and student perceptions of important syllabus components. Journal on Excellence in College Teaching, 10(1), 5-21.

Grunert O'Brien, J., Millis, B.J., \& Cohen, M.W. (2008). The course syllabus: A learning-centered approach (2nd ed.). San Francisco, CA: Jossey-Bass.
Hockensmith, S.F. (1988). The syllabus as a teaching tool. The Educational Forum, 52(4/Summer), 339-351.

Mager, R.F. (1984). Preparing instructional objectives. Belmont, CA: Pitman Learning Inc.

Matejka, K. \& Kurke, L. (1994). Designing a great syllabus. College Teaching, 4(3), 115-117.

Nilson, L. (1998). Teaching at its best: A researchbased resource for college instructors. Bolton, MA: Anker Publishing Co.

Nilson, L. (2008). The graphic syllabus and the outcomes map. San Francisco, CA: Jossey-Bass Inc.

Parkes, J. \& Harris, M. (2002). The purposes of a syllabus. College Teaching, 50(2), 55-61.

Parkes, J., Fix, T., \& Harris, M. (2003). What syllabi communicate about assessment in college classrooms. Journal on Excellence in College Teaching, 14(1), 61-83.

Schonfeld, I.S., Rasmussen, E., Nieto, R., \& Sims, C. (1989). Enhancing undergraduate achievement in educational psychology with instructional objectives. Education, 109(2), 165-169.

Shulman, L.S. (2004). Teaching as community property: Essays on higher education. San Francisco, CA: Jossey-Bass Inc.

\section{Biographies}

Jeanette McDonald is Manager of Educational Development in the Office of Teaching Support Services at Wilfrid Laurier University (jmcdonald@wlu.ca).

Gillian Siddall is Dean of the Faculty of Social Sciences and Humanities and Associate Professor in the Department of English at Lakehead University (gsiddal@lakeheadu.ca).

Deena Mandell is Associate Professor in the Faculty 
of Social Work at Wilfrid Laurier University (dmandell@wlu.ca).

Sandy Hughes is Director of Teaching Support Services at Wilfrid Laurier University (shughes@wlu.ca). 